\title{
PHYSICAL FITNESS CHANGES IN GIRLS FROM THE 11TH GRADES PROMOTING THEIR PHYSICAL SELF-DEVELOPMENT AND TRAINING THEIR LEAST DEVELOPED PHYSICAL QUALITIES
}

\author{
Vida Ivaškiené ${ }^{1}$, Leonas Meidus ${ }^{2}$ \\ Lithuanian Academy of Physical Education, Kaunas ${ }^{1}$, Vilnius Pedagogical University, Vilnius ${ }^{2}$, Lithuania
}

\begin{abstract}
Vida Ivaškienė. Doctor of Social Sciences (Educational Science). Associated Professor at the Department of Sports Pedagogics and Psychology at Lithuanian Academy of Physical Education. Research interests — physical education and self-education of children and adults; stimulation of physical development of schoolchildren.
\end{abstract}

\begin{abstract}
The aim of the research was to determine the changes in physical fitness of girls from the 11th grades promoting their self-education and training their least developed physical qualities.

The sample of the research included one experimental and one control group, each consisting of 24 female subjects $(n=48)$ from the X school in Klaipeda. The subjects of each group were selected using the random sampling method. Each group had two weekly PE lessons according to the Lithuanian General Physical Education Curriculum.

Testing physical fitness based on the guidelines of the Eurofit tests was performed in the middle of September, 2003 and the middle of April, 2004. The pedagogical experiment lasted for 7 months. To determine physical fitness of subjects, the Eurofit tests were used in the following order: sit-and-reach, standing broad jump, sit-ups, bent arm hang, shuttle run $10 \times 5$ metres. The results were assessed according to the National Eurofit Reference Scales.

It was found that physical fitness of girls from the 11th grades was low: according to the Lithuanian Eurofit Reference Scales, the test score in standing broad jump was 3, the test score in sit-and-reach, sit-ups and shuttle run $10 \times 5 \mathrm{~m}$ was 4 and the test score in bent arm hang was 5. In the first tests it was determined that the least developed traits in subjects were the strength of their leg and abdominal muscles and suppleness. For the experimental group, the physical education programme was modified with greater focus on training strength and suppleness.

PE lessons for the experimental group included training pupils' awareness about PE and promoting of self-education. For this reason, the girls were taught to calculate and evaluate their body mass index, they had theoretical lessons about the importance of strength and suppleness as physical qualities and methods how to train them, the importance of exercising, methods of stretching and personal exercising, self-assessment of physical condition.

The programme designed to promote the need for self-development and to train strength and suppleness had a positive effect on physical fitness changes in girls: most of physical qualities increased significantly in girls from the experimental group.
\end{abstract}

Keywords: physical fitness, physical qualities, physical self-development.

\section{INTRODUCTION}

$\mathrm{P}$ hysical fitness among Lithuanian pupils has been constantly decreasing (Volbekienè, Kavaliauskas, 2003; Volbekienè, Griciūtè, 2007). Two (or even three) weekly Physical education (PE) lessons at school can not compensate adequately the lack of schoolchildren's physical activity. If supplementary educational measures are not provided, the tendency toward decreasing physical activity in pupils can be observed star- ting already from the fifth grade (Kardelis et al., 2001). Therefore, in search for effective ways to promote physical activity, schoolchildren's PE has to be supplemented with measures that can form the need for physical self-development.

PE teachers have an important role in developing schoolchildren's awareness about the relations between physical activity and health and in forming the need for physical self-development. 
It is essential to seek for schoolchildren's understanding of the asignments given to them and to make certain that their requirements are suitable for each pupil (Ивашкене, 1990; Hopkins et al., 1998). To achieve these objectives, we need to know pupils' needs, provide them with information about the effect of physical exercises on human health, body shape and physical fitness.

Although physical self-education has been investigated in terms of developing effective technologies to promote students' physical self-education (Tubelis, 2001; Poteliūnienè et al., 2006), not much research deals with different means of influence, that would attempt to form a positive attitude in schoolchildren of different ages toward physical self-development as one of the factors capable of affecting their health. Few studies have analysed the effects of consistent training of the least developed physical qualities on the physical fitness changes in schoolchildren.

In the present study the research problem is revealed by a problem-oriented question, whether knowledge about PE and healthy lifestyle, the development of skills needed for self-awareness and self-control of physical condition, physical activity that meets personal needs, promotion of the need for physical self-development and training of the least developed physical qualities are effective means of increasing physical fitness in girls from the upper grades.

Research object is the changes in physical fitness of girls from the upper (11th) grades.

Hypothesis. Knowledge about PE and healthy lifestyle, learning how to observe and control personal physical condition, promotion of the need for physical self-development and training of the least developed physical qualities have a positive effect on physical fitness changes in girls from upper grades.

The aim of the research is to determine the changes in physical fitness of girls from the upper grades through their self-education and training of the least developed physical qualities.

The objectives based on the research aim were the following:

1. To determine and evaluate physical fitness of the girls of the 11th grades.

2. To identify the subjects' least developed physical qualities, to design the programme for training them and a physical self-education program.

3 . To determine the effect of the designed programme on subjects' physical fitness.
The following methods were applied in conducting the research: 1. Literature review. 2. Antropometrics. 3. Physical fitness testing. 4. Pedagogical experiment. 5. Mathematical statistics.

The scope of the research included one experimental and one control group, each of them consisting of 24 female subjects $(n=48)$ from the $\mathrm{X}$ school in Klaipeda. The subjects for each group were selected using the random sampling method. The data for each group were tested for normal distribution using a Kolmagorov-Smirnov test. Each group had two weekly PE lessons according to the Lithuanian General Physical Education Curriculum.

Antropometrical measurements (height, weight) were performed, including body mass index (BMI) (Heyward, 2002). Testing of physical fitness based on the guidelines of the Eurofit tests was performed in the middle of September, 2003 and the middle of April, 2004 (the pedagogical experiment lasted for 7 months). To determine physical fitness of subjects, the Eurofit tests were used in the following order: sit-and-reach, standing broad jump, sit-ups, bent arm hang, shuttle run $10 \times 5$ metres. The results were assessed according to the national Eurofit Reference Scales (Eurofitas: fizinio pajegumo testai ir metodika, 2002).

In the first tests it was determined that the least developed traits in subjects were strength of their leg and abdominal muscles and suppleness. For the experimental group, the physical education programme was modified with greater focus on training strength and suppleness.

The exercises used for leg muscle training were jumps from a gymnastics bench, jumps with bent knees, jumps over a bench, jumps over a rope, high and long jumps, sit-ups, tiptoes, multiple jumps. The exercises used to train abdominal muscles were movements with legs in a standing and lying position, different passes of a stuffed ball with legs in a lying position, throws of a stuffed ball in a sitting and kneeling position, crunches, sit-ups, knee ups from a hanging position. Flexibility was trained through stretching exercises, bends, leaning with and without tools movements.

PE lessons for the experimental group included training of pupils' awareness of $\mathrm{PE}$ and promotion of self-education. For this reason, the girls were taught to calculate and evaluate their body mass index (BMI), they had theoretical lessons about the importance of strength and suppleness as phy- 
sical qualities and methods how to train them, the importance of exercising, methods of stretching and personal exercising, self-assessment of physical condition. The physical education programme of the control group was not modified.

The research results have been processed by using the SPSS 13.0 software. The statistical significange was calculated according to a Student's $t$ test and the level of reliability $p$.

\section{RESEARCH RESULTS AND ANALYSIS}

At the beginning of the research, the mean height of the control group was $170.1 \pm 2.2 \mathrm{~cm}$, while at the end of the research the mean height was $171.2 \pm 2.3 \mathrm{~cm}$; the mean height of the experimental group was $171.2 \pm 2.47$ and $171.5 \pm 2.7 \mathrm{~cm}$ respectively (Fig. 1).

The girls' weight during the research period practically did not change: at the beginnning of the research the mean weight of the control group was $57.1 \pm 2.4 \mathrm{~kg}$ and at the end of the research the mean weight was $57.2 \pm 2.37 \mathrm{~kg}(\mathrm{t}=0.13 ; \mathrm{p}>0.05)$
(Fig. 2), while the mean weight of the experimental group was $57.4 \pm 3.17$ and $57.3 \pm 3.47 \mathrm{~kg}(\mathrm{t}=0.87$; $\mathrm{p}>0.05)$ respectively. The mean height and weight of the control and experimental groups were similar at the beginning and the end of the research $(p>0.05)$ and did not change significantly during the research $(\mathrm{p}>0.05)$.

After calculating BMI $\left(\mathrm{kg} / \mathrm{m}^{2}\right)$, it was determined that the data obtained from the two groups did not differ $(p>0.05)$ and were within 19.5$19.7 \mathrm{~kg} / \mathrm{m}^{2}$ limits (Fig. 3).

The results of the control and experimental groups in the first sit-and-reach test were similar ( $p>0.05$ ): $25.5 \pm 4.17$ and $25.8 \pm 4.37 \mathrm{~cm}$ respectively (Fig. 4).

After the experimental period, the suppleness in the control group increased by $1.2 \mathrm{~cm}$; however, the difference between the first and the second test was not statistically significant $(t=0.81 ; p>0.05)$. The suppleness in the experimental group increased by $4.3 \mathrm{~cm}$ and was $30.1 \pm 4.5 \mathrm{~cm}$. The difference between the first and the second tests was statistically significant $(\mathrm{t}=2.89 ; \mathrm{p}<0.01)$. According to the Lithuanian

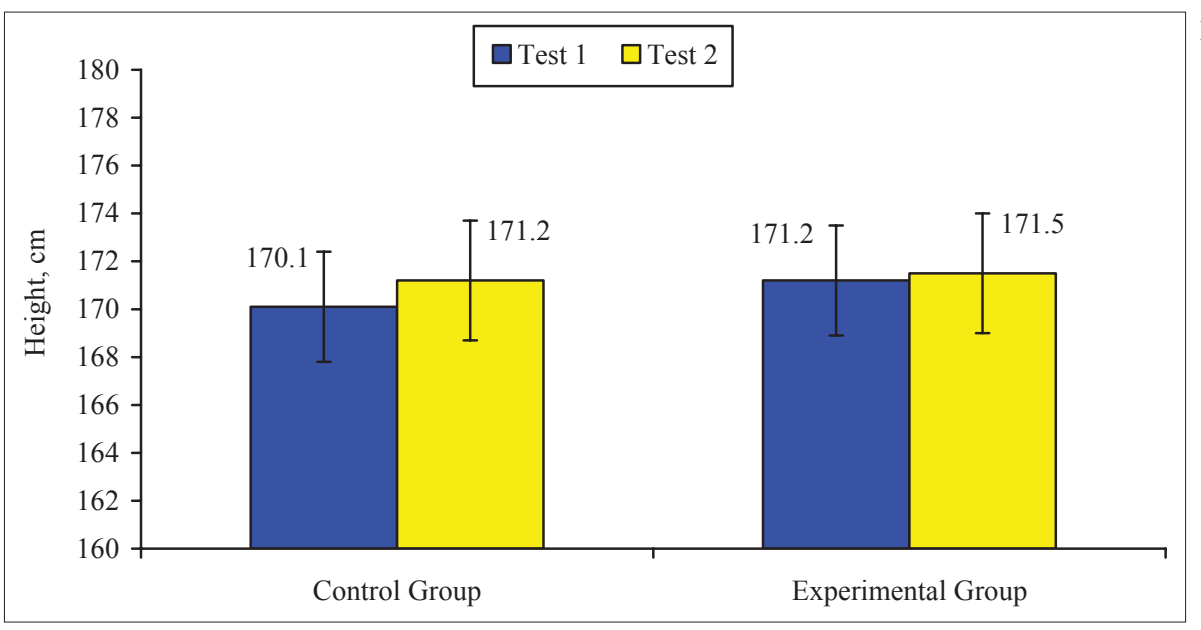

Figure 1. Girls’ height $(\overline{\mathbf{x}} \pm \mathbf{S} \overline{\mathbf{x}})$

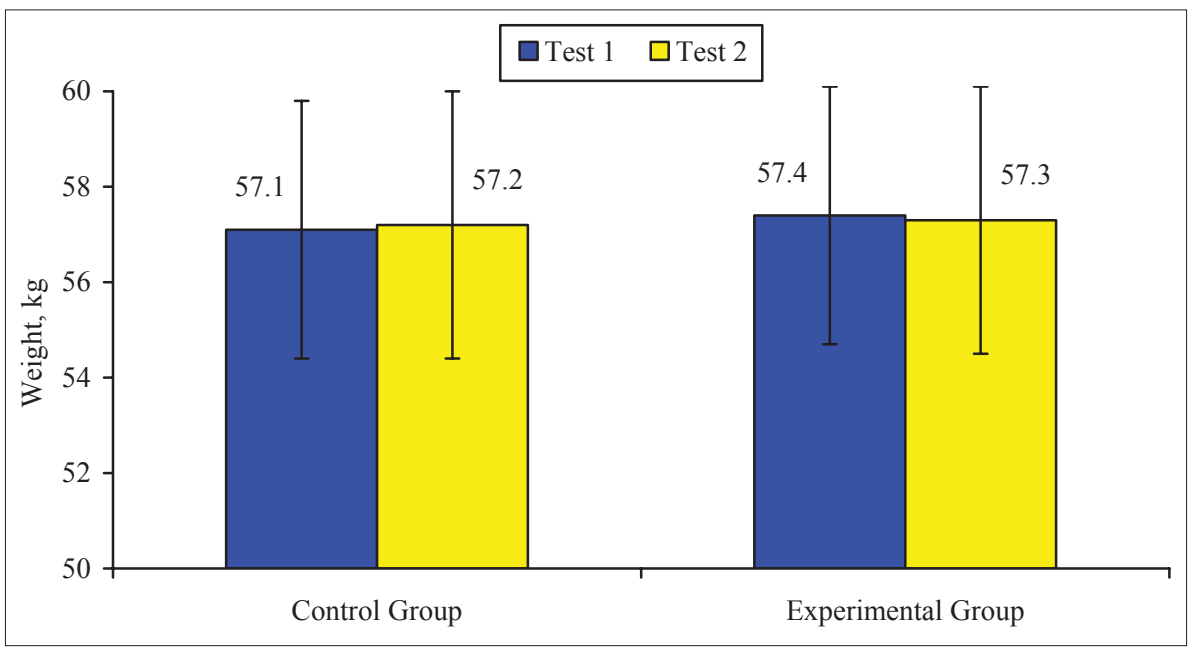

Figure 2. Girls' weight $(\overline{\mathbf{x}} \pm \mathbf{S} \overline{\mathbf{x}})$ 
Figure 3.

Girls' Body mass index $(\overline{\mathbf{x}} \pm \mathbf{S} \overline{\mathbf{x}})$
Figure 4. The results of girls' Sitand-reach test $(\overline{\mathbf{x}} \pm \mathbf{S} \overline{\mathbf{x}})$
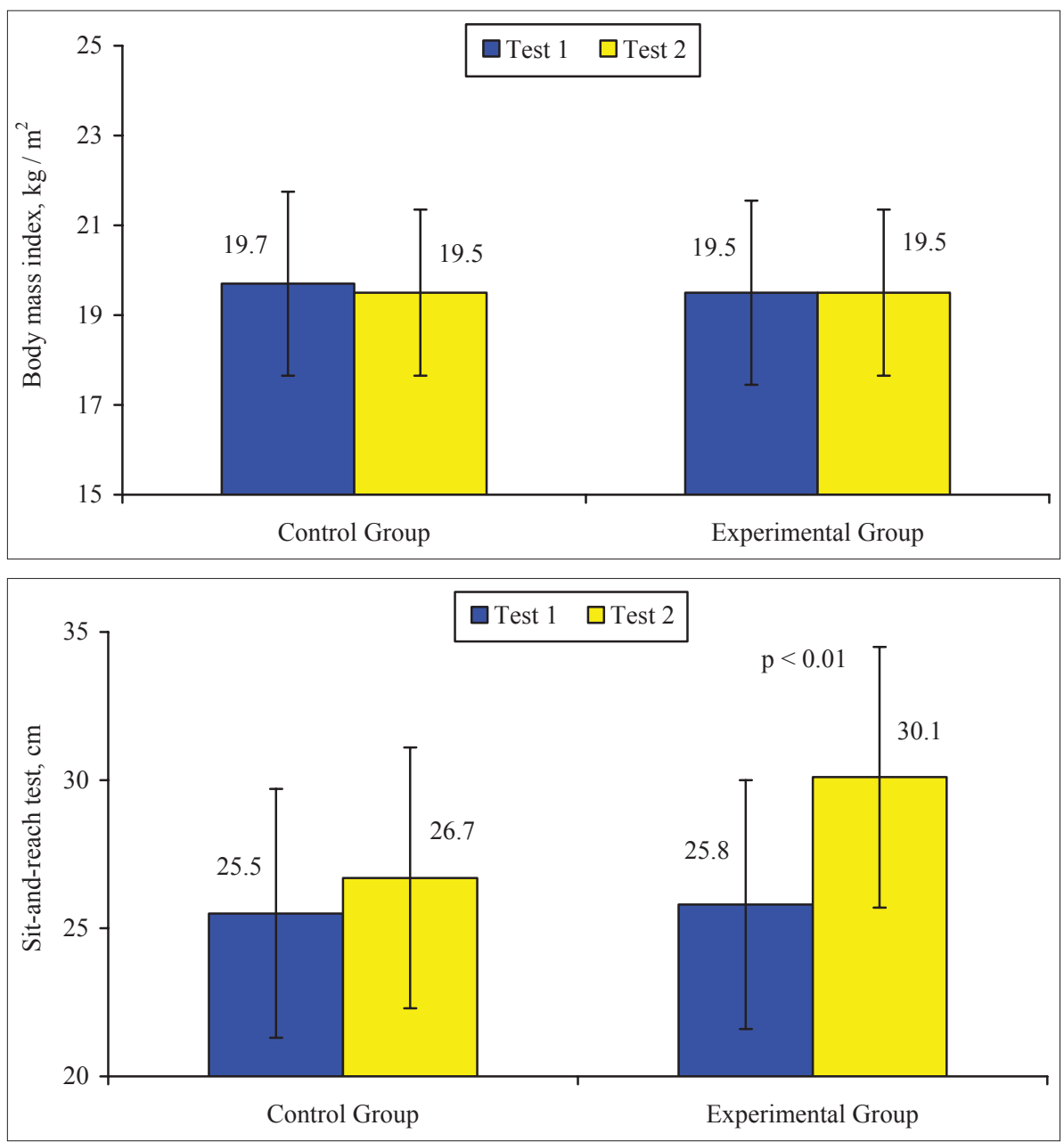

Figure 5. The results of girls' Standing broad jump test $(\overline{\mathbf{x}} \pm \mathbf{S} \overline{\mathbf{x}})$

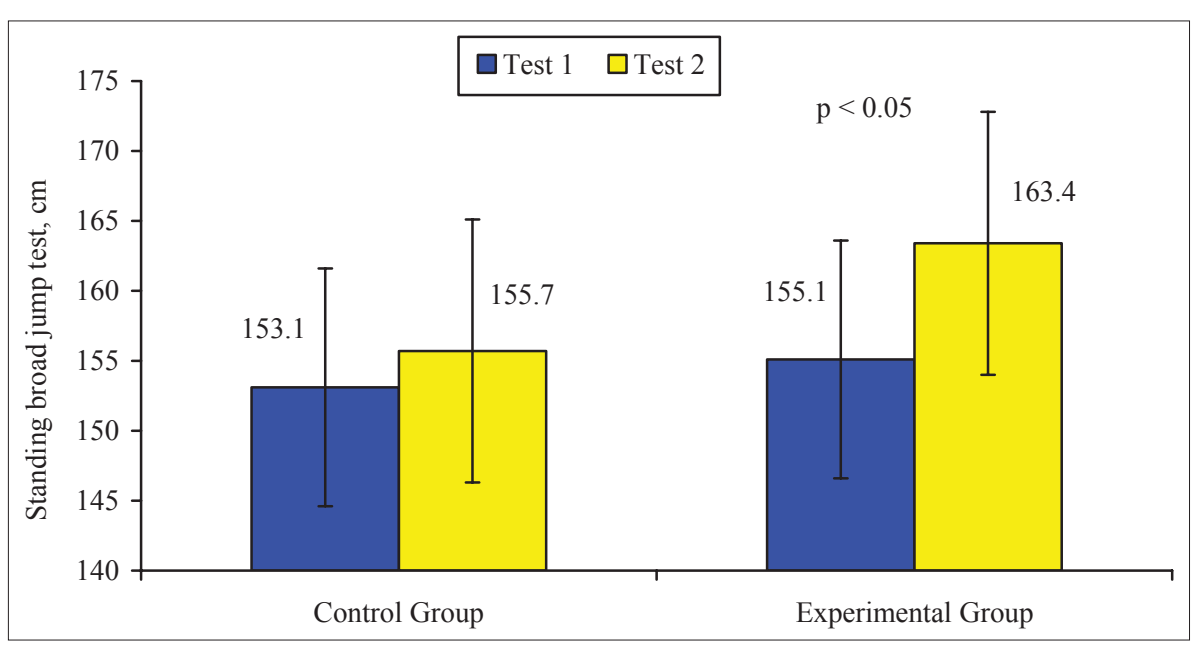

Eurofit Reference Scales (2002), in the first test the score in the control and experimental groups was 4; however, in the second test the control group score was 5 , while the score in the experimental group was 6 .

In the first standing broad jump test, the mean result of the control group was $153.1 \pm 10.17 \mathrm{~cm}$ (Fig. 5) and, in the second test, the mean result was $155.7 \pm 10.27 \mathrm{~cm}$. Thus the change was not statistically significant $(t=0.72 ; p>0.05)$. In the first test, the girls from the experimental group jumped $155.1 \pm 9.2 \mathrm{~cm}$, and in the second test $163.4 \pm 9.17 \mathrm{~cm}$. The increase of $8.3 \mathrm{~cm}$ was statistically significant $(\mathrm{t}=2.56 ; \mathrm{p}<0.05)$. According to the national Eurofit Reference Scales, the score of the control group was 3 in the first and second tests, while the score of the experimental group was 3 in the first test and 4 in the second test.

In the first sit-ups test, the control group performed $24.0 \pm 3.2 \mathrm{~N} / 30 \mathrm{~s}$, while in the second test 

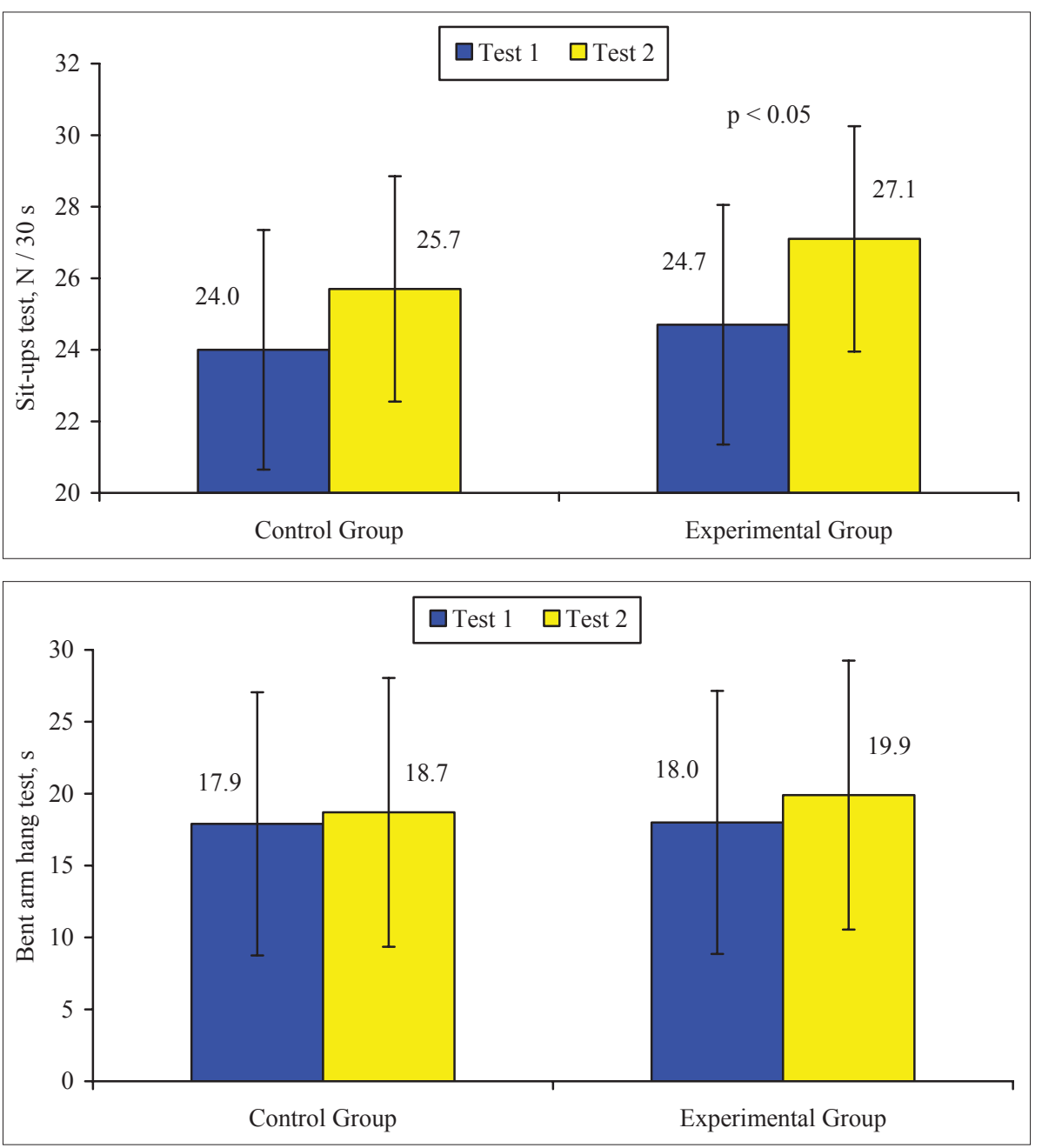

Figure 6. The results of girls' Situps test $(\overline{\mathbf{x}} \pm \mathbf{S} \overline{\mathbf{x}})$

igure 7. The results of girls' Bent arm hang test $(\overline{\mathbf{x}} \pm \mathbf{S} \overline{\mathbf{x}})$

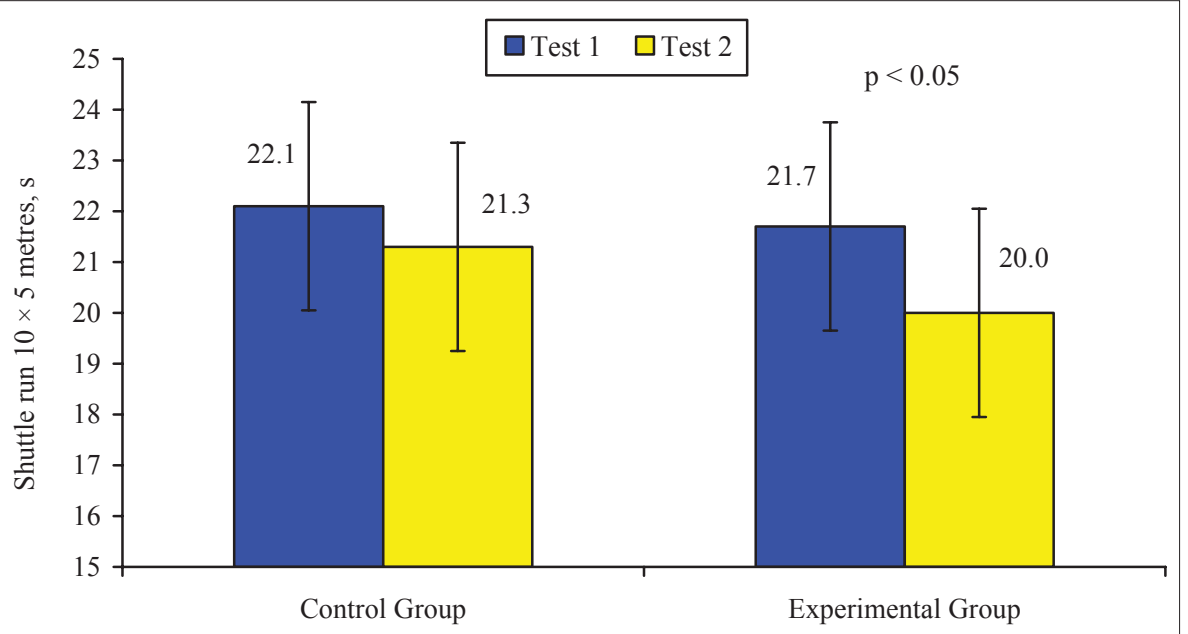

Figure 8 . The results of girls' Shuttle run $10 \times 5$ metres $(\overline{\mathbf{x}} \pm S \overline{\mathbf{x}})$

the control group performed $25.7 \pm 3.3 \mathrm{~N} / 30 \mathrm{~s}$ (Fig. 6). The experimental group performed $24.7 \pm 3.5$ and $27.1 \pm 3.0 \mathrm{~N} / 30$ s respectively. Thus the results of the experimental group improved by $2.4 \mathrm{~N} / 30 \mathrm{~s}$. The difference in the experimental group between the first and the second test was statistically significant $(t=2.09 ; \mathrm{p}<0.05)$, while the difference in the control group was insignificant ( $p>0.05)$. According to the national
Eurofit Reference Scales, the control group in the first test scored 3 and in the second test it scored 5 , while the scores of the experimental group were 4 and 6 respectively.

In the first bent arm hang test, the result of the control group was $17.9 \pm 9.1 \mathrm{~s}$ and in the second test the result was $18.7 \pm 9.3 \mathrm{~s}$ (Fig. 7). The result of the experimental group was $18.0 \pm 9.2 \mathrm{~s}$ and $19.9 \pm 9.4 \mathrm{~s}$ respectively. The increase in perfor- 
ming the bent arm hang test was observed in both groups $(p>0.05)$. In the first and the second test the girls from the control group scored 5 according to the national Eurofit Reference Scales, while the scores of girls from the experimental group were 5 in the first test and 6 in the second test.

The mean result of the control group in the first shuttle run $10 \times 5 \mathrm{~m}$ test was $22.1 \pm 2.1 \mathrm{~s}$ and in the second test the mean result was $21.3 \pm 2.0 \mathrm{~s}$ (Fig. 8). The results of the control group in the shuttle run $10 \times 5 \mathrm{~m}$ over the experimental period statistically did not change $(t=1.62 ; \mathrm{p}>0.05)$. On the other hand, the result of the experimental group in the first shuttle run $10 \times 5 \mathrm{~m}$ test was $21.7 \pm 2.0 \mathrm{~s}$, while in the second test the result was $20.0 \pm 2.1 \mathrm{~s}$. This increase was statistically significant $(\mathrm{t}=2.34 ; \mathrm{p}<0.05)$. According to the Lithuanian Eurofit Reference Scales, the control and experimental groups in the fist test scored 4. However, in the second test the score of the control group was 5, while it was 6 in the experimental group.

\section{DISCUSSION}

The compararative analysis of subjects' height and weight according to the national Eurofit Reference Scales (Eurofitas: fizinio pajegumo testai ir metodika, 2002) and Children's Growth Scales (Tutkuvienè, 1995) indicates that the subjects' data corresponds to the mean data of Lithuanian girls from the upper grades. During the experimental period the girls' height and weight from the control and experimental groups increased insignificantly.

In recent years scientists from other countries pay more attention to the BMI (Himmes, Dietz, 1994; Heyward, 2002). Body mass is normal when BMI is $20-25 \mathrm{~kg} / \mathrm{m}^{2}$, and body mass is ideal when BMI is $22 \mathrm{~kg} / \mathrm{m}^{2}$. In this research the subjects' BMI was $19.5-19.7 \mathrm{~kg} / \mathrm{m}^{2}$ and reflected the girls' general trend toward slenderness that has been noted by D. Lauzier et. al. (1992).

Physical fitness of girls from the upper grades is low: according to the Lithuanian Eurofit Reference Scales, the test score in standing broad jump was 3 , the test score in sit-and-reach, situps and shuttle run $10 \times 5 \mathrm{~m}$ was 4 and the test score in bent arm hang was 5. According to the Lithuanian Physical Education Badge (1996), the girls in the first bent arm hang test scored 1 point and in other tests girls did not score even this lowest point. In the second sit-ups test the control group scored 1 point, while the experimental group scored 3 points. In both bent arm hang tests the control group scored 1 pont while the experimental group scored up to 2 points. In the shuttle run $10 \times 5 \mathrm{~m}$ test the experimental group scored 6 points.

The programme designed to promote the need for self-development and to train strength and suppleness purposefully had a positive effect on the changes in the girls' physical fitness: the results of the experimental group in standing broad jump, sit-ups, sit-and-reach and shuttle run $10 \times 5$ $\mathrm{m}$ tests increased significantly $(\mathrm{p}<0.05)$, while in the control group only a slight increase of physical fitness was observed. These observations correspond to the data obtained by researches who noted that the parameters of pupils' physical fitness increase very insignificantly throughout the school year (Zuoziene, 1998). The research data supported the findings of the previous research that the least developed physical qualities if trained purposefully would improve (Ивашкене, Скирене, 2005). The increase of suppleness in girls as the result of systematic education has been determined by V. Paliušienè et al. (2003).

The data obtained in the research support the opinion of other authors who state that in PE lessons physical load has to be planned and analysed and that PE teachers have to choose moderate physical activity, teach pupils health-enhancing physical exercises and instil in them the joy of movement (Feingold, Barrete, 1991). Special attention in PE lessons has to be given to the transfer of knowledge, skills and abilities how to exercise for self-development (Bunker, 1998; Zuozienè, 1998).

In conclusion, it can be stated that if in PE lessons girls' self-education is promoted by different means and more attention is given to the training of the least developed physical traits (in the case of this research to strength and suppleness), physical fitness parameters increase faster compared to the increase when the standard methods are used. The positive effect of educational factors on physical fitness has been determined by I. J. Zuozienè (1998), O. Batutis and K. Kardelis (1998).

The research hypothesis was comfirmed: knowledge about PE and healthy lifestyle, learning to observe and evaluate personal physical condition, physical self-education and training of the least developed physical qualities have a 
positive effect on the change of physical fitness in girls from the upper grades.

\section{CONCLUSIONS}

1. Physical fitness of girls from the upper grades is low: according to the Lithuanian Eurofit Reference Scales, the test score in standing broad jump was 3 , the test score in sit-and-reach, situps and shuttle run $10 \times 5 \mathrm{~m}$ was 4 and the test score in bent arm hang was 5 .
2. The least developed physical qualities in the girls from the upper grades are strength and suppleness.

3. The programme designed to promote the need for self-development and to train strength and suppleness had a positive effect on physical fitness changes in girls: most of physical qualities improved significantly in girls from the experimental group $(\mathrm{p}<0.05)$.

\section{REFERENCES}

Batutis, O., Kardelis, K. (1998). Fizinès būklès savianalizè kaip požiūrio i fizini aktyvumą formavimosi veiksnys. Pirmosios respublikinés jaunuju mokslininku konferencijos „Lietuva be mokslo - Lietuva be ateities" medžiaga. T. 3 (pp. 147-152). Vilnius: Technika.

Bunker, L. (1998). Psycho-physiological contributions of physical activity and sports for girls. Research Digest, 3 (1), President's Council of Ph FLSp, Washington.

Eurofitas: fizinio pajegumo testai, metodika. Lietuvos moksleiviu fizinio pajégumo rezultatai. (2002). 2-asis pataisytas ir papildytas leidimas. Parengè V. Volbekienè, S. Kavaliauskas. Vilnius: LSIC.

Feingold, R. S. C., Barrete, G. T. (1991). Strategies for school fitness curricural modifications: An integrative model utilizing the superordinate goal theory. Sport and Physical Activity, 12, 54-59.

Heyward, V. H. (2002). Advanced Fitness Assessment Exercise Prescription. University of New Mexico: Human Kinetics.

Himmes, J. H., Dietz, W. H. (1994). Guidelines for overweight in adolescent preventive services: Recommendation from an expert committee. The American Journal of Clinical Nutrition, 59, 307.

Hopkins, D., Ainsow, M., West, M. (1998). Kaita ir mokyklos tobulinimas. Vilnius: Tyto Alba.

Kardelis, K., Kavaliauskas, S., Balzeris, V, (2001). Mokykline kūno kultūra: realijos ir perspektyvos: monografija. Kaunas: LKKA.

Lauzier, D., Guiguier, M., Chau, N. P. (1992). Prelevance of obesity: A comparative survey in France, the United Kingdom and the United States. International Journal of Obesity, 16.

Lietuvos kūno kultūros ženklas: testai ir metodiniai nurodymai. (1996). Vilnius: Resp. sp. inform. ir spec. tobulinimo centras.

Paliušienè, V., Gaigalienè, G., Ramonaitis, V. (2003). Lankstumo ugdymas, naudojant tempimo pratimus, ir jo itaka žmogaus organizmui. Kūno kultūros ir sveikatos ugdymo šiuolaikines problemos: moksl. resp. konf. pranešimu medžiaga (pp. 49-50). Klaipèda: KU.

Poteliūnienè, S., Veršinskas, R., Muliarčikas, A. (2006). Mykolo Romerio universiteto studenčiu fizinès saviugdos prielaidos. Ugdymas. Küno kultūra. Sportas, 4 (63), $90-95$.
Tubelis, L. (2001). Studentu fizinès saviugdos skatinimo sistema ir jos efektyvumas: daktaro disertacija. Vilnius.

Tutkuviene, J. (1995). Vaiku augimo ir brendimo vertinimas. Vilnius: Vilspa.

Volbekienė, V., Griciūtè, A. (2007). Health-related physical fitness among schoolchildren in Lithuania: A comparison from 1992 to 2002. Scandinavian Journal of Public Health, 35, 235-242.

Volbekienè, V., Kavaliauskas, S. (2003). Changes in physical fitness of Lithuanian students in respect to age. New ideas in Sport Sciences: Current Issues and Perspectives: 8th International Scientific Conference "Sport Kinetics 2003" \& 11th Conference on Physical Education and Sport in Scientific Research: Papers. Poland, 19-21 September, 2003. Warszawa-Poznan-Leszno, Part 1, p. $315-318$.

Zuozienè, I. (1998). Kūno kultūros ir sveikos gyvensenos žiniu itaka moksleiviu fiziniam aktyvumui: daktaro disertacija. Kaunas.

Ивашкене, В. (1990). Улучиение физического состояния школьников воспитанием их сознательной и активной детельности на занятиях физической культурьи: дисс. на соиск. учён. степ. пед. наук. Каунас: ЛИФК.

Ивашкене, В., Скирене, В. (2005). Показатели физической подготовленности школьниц как результат развития отстающих физических качеств. Физическая культура и спорт в системе образования. Здоровье сберегающие технологии и формирование здоровья: материаль международного научного симпозиума, Гродно, Беларусь, 6-10 мая 2005 года (с. 210-213). Гродно: ГрГУ. 


\title{
VIENUOLIKTOKIŲ FIZINIO PAJĖGUMO KAITA SKATINANT FIZINĘ SAVIUGDĄ IR UGDANT SILPNIAUSIAI IŠLAVINTAS FIZINES YPATYBES
}

\author{
Vida Ivaškiene் $\dot{e}^{1}$, Leonas Meidus ${ }^{2}$ \\ Lietuvos kūno kultūros akademija, Kaunas ${ }^{l}$, Vilniaus pedagoginis universitetas, Vilnius ${ }^{2}$, Lietuva
}

\section{SANTRAUKA}

Tyrimo tikslas - nustatyti vienuoliktokių fizinio pajėgumo kaitą skatinant fizinę saviugdą ir ugdant silpniausiai išlavintas fizines ypatybes.

Tiriamają imti sudare 24 eksperimentinès ir 24 kontrolinės grupès merginu $(n=48)$ iš Klaipèdos $N$ mokyklos. Eksperimentinès ir kontrolinès grupès imtys buvo sudarytos atsitiktinès atrankos būdu. Abi grupès turèjo dvi savaitines kūno kultūros pamokas, kurios vyko pagal Lietuvos bendrąsias kūno kultūros programas.

Fizinio pajègumo testavimas pagal Eurofito programos reikalavimus atliktas $2003 \mathrm{~m}$. rugsėjo viduryje ir $2004 \mathrm{~m}$. balandžio viduryje. Pedagoginio eksperimento trukmė -7 mẻnesiai.

Fiziniam pajègumui nustatyti buvo naudojami Eurofito testai išvardyta seka: „Sèstis ir siekti“, šuolis $\mathfrak{i}$ toli iš vietos, „Sèstis ir gultis“, kybojimas sulenktomis rankomis, „10 $\times 5$ m bègimas šaudykle“. Gauti rezultatai vertinti pagal Eurofito orientacines vertinimo skales (Eurofitas. Fizinio pajegumo testai ir metodika, 2002).

Atlikus pirmą testavimą nustatyta, kad vienuoliktokiu fizinis pajègumas prastas: pagal Eurofito orientacines vertinimo skales 3 balų vertinimo ribose yra šuolio i tolị rezultatai, 4 balų - testų „Sèstis ir siekti“, „Sèstis ir gultis“, testo „10 × 5 m bėgimas šaudykle“, 5 balu — kybojimo sulenktomis rankomis. Išaiškèjo, kad silpniausiai išlavinta yra tiriamujų kojų ir pilvo raumenų jèga bei lankstumas. Eksperimentinei grupei buvo sudaryta kūno kultūros programa, kurioje daugiau dèmesio skirta jẻgos ir lankstumo lavinimui. Per kūno kultūros pamokas buvo ugdomas eksperimentinès grupès merginų sąmoningumas kūno kultūros srityje, skatinama fizinè saviugda. Tuo tikslu merginos buvo išmokytos apskaičiuoti savo kūno masès indeksą ir ji îvertinti, joms buvo vestos teorinès pamokos apie jègos ir lankstumo fizinių ypatybių reikšmę ir ugdymo metodiką, mankštos svarbą, raumenų tempimo ir savarankiško mankštinimosi metodiką, mokoma vertinti savo fizinę būklę.

Fizinès saviugdos skatinimo bei jègos ir lankstumo ugdymo programa turèjo teigiamą ịtaką merginu fizinio pajëgumo kaitai: eksperimentinèje grupèje smarkiai pagerejo daugumos fizinių ypatybių rodikliai.

Raktažodžiai: fizinis pajègumas, fizinès ypatybès, fizinè saviugda.

Gauta 2007 m. gegužès 13 d.

Received on May 13, 2007

Priimta 2007 m. rugsejjo $19 \mathrm{~d}$.

Accepted on September 19, 2007
Vida Ivaškienè

Lithuanian Academy of Physical Education

(Lietuvos kūno kultūros akademija)

Sporto str. 6, LT-44221 Kaunas

Lithuania (Lietuva)

$\mathrm{Tel}+37037302645$

E-mail v.ivaskiene@lkka.1t 